\title{
Conditions influencing incoming global solar radiation in Hornsund (Spitsbergen) in spring 2015
}

\author{
Joanna USCKA-KOWALKOWSKA ${ }^{1 *}$, Krzysztof M. MARKOWICZ², \\ Rajmund PRZYBYLAK ${ }^{1}$ and Andrzej ARAŹNY ${ }^{1}$ \\ ${ }^{1}$ Department of Meteorology and Climatology, Faculty of Earth Sciences, \\ Nicolaus Copernicus University, Lwowska 1, 87-100 Toruń, Poland \\ <joannauk@umk.pl><rp11@umk.pl><andy@umk.pl> \\ 2 Institute of Geophysics, Faculty of Physics, University of Warsaw, \\ Pasteura 7,02-093 Warsaw,Poland <kmark@igf.fuw.edu.pl> \\ * corresponding author
}

\begin{abstract}
This article analyses the conditions affecting the incoming global solar radiation in Hornsund (Spitsbergen) in spring of 2015. Incoming solar radiation turned out to be average for the season under analysis, as compared with longer-term data. The clearness index $\left(K_{\mathrm{T}}\right)$ was 0.46 , and was mainly determined by the extent of cloudiness. As a result of differences in the length of day, sunshine duration in May was greater than in April. Incoming solar radiation to the earth's surface is also affected by the atmospheric optical properties. The average value of aerosol optical depth (AOD) at $500 \mathrm{~nm}$ in Hornsund in spring of 2015 was 0.087 . In the analysed period, increased values of $\mathrm{AOD}$ at $500 \mathrm{~nm}$ (up to 0.143 ) were observed, although these are not record values. Over April and May, the greatest part of optical depth was comprised of anthropogenic aerosols $(41 \%)$, followed by marine aerosols $(26 \%)$, desert dust $(21 \%)$ and biomassburning aerosols $(12 \%)$. This indicates the significant role of the anthropogenic factor in the climatic conditions of Spitsbergen.
\end{abstract}

Key words: Arctic, Spitsbergen, global solar radiation, cloudiness, sunshine duration, aerosol optical depth.

\section{Introduction}

Solar radiation is a fundamental factor influencing the climate of every region of the earth (Przybylak 2016). The amount of energy reaching the earth's surface is determined by factors which are astronomical (duration of the day and solar elevation angle), geophysical (volcanic eruptions), meteorological (cloud cover, atmospheric transparency and ground surface albedo), and in the last 
150-200 years by the increasing effect of anthropogenic factors (e.g. gaseous and particulate air pollution). In polar regions, astronomical factors cause extreme variations in the incoming solar radiation over the annual cycle, mainly associated with the occurrence of polar day and night (see figure 1.3 in Przybylak 2016). It is worth remembering that the total incoming solar energy to the top of the atmosphere in summer is greater here than in equatorial regions, while in polar nights during the winter it is zero (Budyko 1971; Hartmann 1994).

Gavrilova (1963), Marshunova and Chernigovskii (1971), and Ohmura (1981, 1982) provide excellent reviews of historical developments in radiation studies up to about 1980, and, for the 35 years up to present. Such a review has also been presented by Przybylak (2016), who concluded in his review that, "although, it is possible to find a great quantity of literature and points of view on the different aspects of the radiation regime in the Arctic, our knowledge about the climatology of the radiation balance and its components is still meagre." Due to sparse network of actinometric station in the Arctic, improvement of knowledge about incoming solar radiation is possible mainly through development of better satellite and reanalyses projects. Both of these types of data must be calibrated with the observational data, and therefore any new data, as presented e.g. in our paper, are very important.

For Hornsund, such knowledge is better than for the entire Arctic, but is also still limited in many aspects. Meteorological and anthropogenic factors determining incoming solar radiation have been particularly meagrely investigated. Hence, these issues are the main subject of the research whose results are presented below. The first measurements of global solar radiation in Hornsund were made as part of the International Geophysical Year in the years 1957-1958 (Głowicki 1985; Styszyńska 2013). Later measurements were taken over various periods as part of polar expeditions (Styszyńska 2013). Incoming solar radiation in Hornsund over a multi-year period and in the context of astronomical and meteorological factors (cloudiness and sunshine duration) has been presented in a monograph edited by Marsz and Styszyńska (2013). The issue of the extent of sunshine duration in the polar zone, including in Hornsund for the period 1979-2014, has also been addressed by Matuszko et al. (2015) and for the period 1978-2009 by Marsz (2013). This latter author gave a detailed description of the variability of cloudiness, both over the annual cycle and long-term. The relationship between cloudiness and atmospheric circulation on Spitsbergen was studied in 1983-2013 by Lipiński and Łupikasza (2016), and satellite imagery-based studies of the extent of cloudiness over Svalbard by Kotarba and Widawski (2008).

Studies of atmospheric aerosols have been conducted at various points in the Arctic for many years (Quinn et al. 2007; Tomasi et al. 2007; Toledano et al. 2012; Lisok et al. 2016). A range of works deal with the optical properties of aerosols in Hornsund, such as Rozwadowska et al. (2008); Rozwadowska and Sobolewski (2010); Toledano et al. (2012). Studies have also covered, among 
others, issues relating to the influence of air mass inflow (Rozwadowska et al. 2010) and volcanic eruptions (Karasiński et al. 2014) on the optical properties of aerosols.

This article presents factors determining the incoming solar radiation in Hordsund in spring of 2015. Factors both astronomical (day length, solar elevation angle) and meteorological (cloudiness, sunshine duration, atmospheric aerosol optical depth and precipitable water content in a vertical column of the atmosphere) were taken into account. The issue of incoming solar radiation is also presented in relation to type of synoptic situation and back trajectories of air masses flowing over Hornsund.

\section{Study area}

The research was conducted in Hornsund, Spitsbergen, at the Polish Polar Station both in the Meteorological Garden and on the Wilczekodden (Fig. 1). The station is situated on the northern shore of the Hornsund (SW Spitsbergen) at $10 \mathrm{~m}$ a.s.l., and its geographical coordinates are $\varphi=77^{\circ} 00^{\prime} \mathrm{N}, \lambda=15^{\circ} 33^{\prime} \mathrm{E}$. The surrounding area has a varied relief; there are mountains of 500-700 m a.s.l. to the north, resulting in a maximum horizon obstruction of $14.2^{\circ}$ at an azimuth of $16^{\circ}$, while at azimuth $50-300^{\circ}$ horizon obstruction is minor, not exceeding $5^{\circ}$ (Styszyńska 2013). The point at which global solar radiation is measured (Wilczekodden, Fig. 1) is about $700 \mathrm{~m}$ to the southeast of the Polish Polar Station and has less horizon obstruction than the Meteorological Garden.

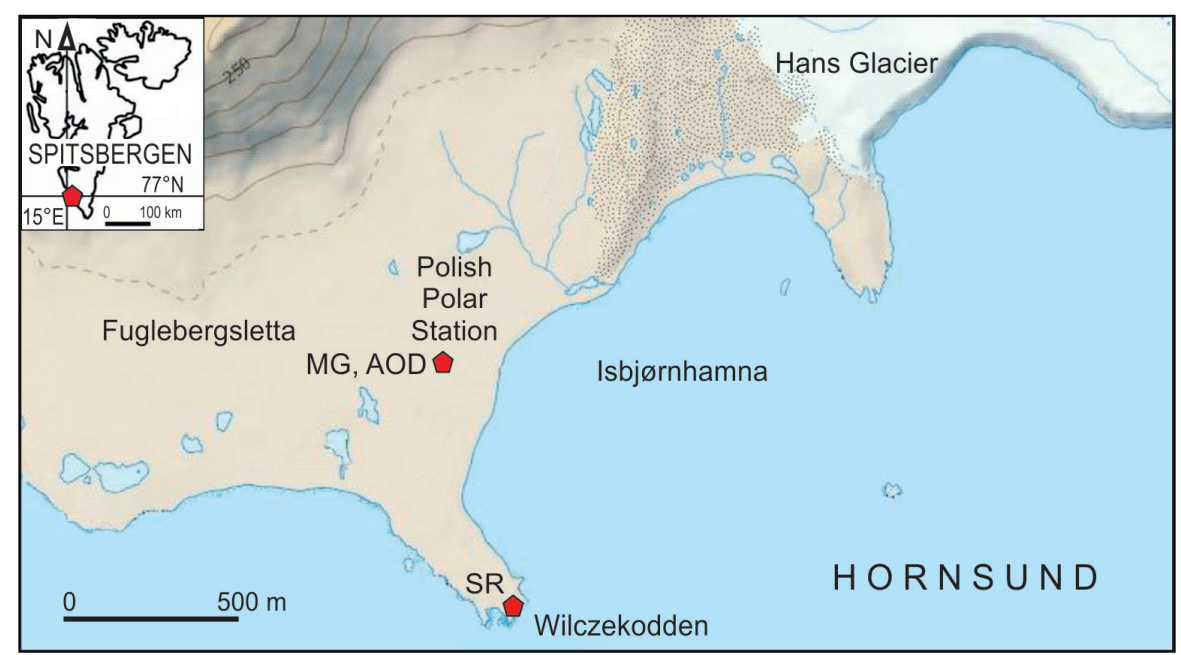

Fig. 1. Location of measuring stations at the Polish Polar Station in Hornsund.

Legend: MG - Meteorological Garden, AOD - measuring point for atmospheric aerosol optical depth, SR - measuring point for components of solar radiation balance. 


\section{Materials and methods}

The study uses the results of measurements and meteorological observations carried out in the Polish Polar Station in Hornsund as part of standard synoptic observations (WMO station No. 01003) and as part of the Polish-Norwegian research project AWAKE 2 and the Contemporary and historical changes in the Svalbard climate and topoclimates project funded by the Polish National Science Center. Standard measurements and meteorological observations (of cloudiness, sunshine duration and others) and AOD (aerosol optical depth) measurements were conducted in the Meteorological Garden (Fig. 1). Sunshine duration was measured using a Campbell-Stokes heliograph, while cloudiness was evaluated visually in oktas. Components of solar radiation balance were measured using a CNR4 (Kipp\&Zonen) radiometer on the Wilczekodden. AOD and total water vapour content in a vertical column of the atmosphere were measured using a Microtops II handheld sun photometer. Measurements of AOD and precipitable water content were taken hourly only when the solar disc was not obscured by clouds. In 2015 in Hornsund, for April and May combined, 52 measurement series were made in 9 days in which conditions were favourable (Table 1). Incoming solar radiation to the earth's surface in Hornsund is presented as daily sums reaching a horizontal surface (in $\mathrm{MJm}^{-2}$ ) and as those sums' relation to analogous sums at the top of the atmosphere (clearness index, $K_{\mathrm{T}}$ ).

The work uses the average daily amount of cloudiness calculated from 8 fixed observations made every three hours. Sunshine duration is presented as the daily sum of hours of direct solar radiation influx.

Atmospheric transparency during clear sky conditions depends mainly on the optical properties of aerosols and their water vapour content. AOD was used as the main parameter for describing atmospheric aerosol content at 4 wavelengths: $380,500,870$ and $1020 \mathrm{~nm}$. Each series of measurements included 5 measurements taken in quick succession, one of which was selected for further analysis. During a single measurement ( $\mathrm{ca} .10 \mathrm{~s}$ ) the Microtops II sunphotometer takes 32 recordings of direct solar radiation for each of the spectral channels. Then, the 4 maximum values (indicating the optimal orientation of the device towards the sun) are used further. Average values and standard deviations are determined. As part of a single series of measurements, the observation with the lowest standard deviation is selected. The extent of aerosol is represented by the Ångström exponent (AE), which was calculated for the 500 and $870 \mathrm{~nm}$ wavelengths:

$$
A E=-\frac{\ln \tau / \tau_{0}}{\ln \lambda / \lambda_{0}}
$$

where:

$\tau, \tau_{0}-$ AOD for the wavelength $\lambda(500 \mathrm{~nm})$ and $\lambda_{0}(870 \mathrm{~nm})$. 
The issue of solar radiation influx into Hornsund is also presented in relation to inflowing air masses. The work uses the catalogue of atmospheric circulation types of Niedźwiedź $(2013,2016)$ for Spitsbergen. This classification describes the type of pressure system (anticyclone - index "a", cyclone - index "b") and direction of advection according to the eight principal directions of the compass rose. The classification further distinguishes a central anticyclonic situation $(\mathrm{Ca})$, an anticyclonic ridge (Ka), a centre of a cyclone $(\mathrm{Cc})$ and a cyclonic trough $(\mathrm{Bc})$, while other situations are indicated as " $\mathrm{X}$ " (for more details, see Niedźwiedź 2013). This work only takes into account circulation types which occurred for at least 5 days, so as to avoid inclusion of random values from individual days. This condition is satisfied for a total of 51 days of the analysed period.

The issue of incoming solar radiation is also presented in relation to back trajectories of air masses flowing over Hornsund. The 144-hours back trajectories were computed based on HYbrid Single-Particle Lagrangian Integrated Trajectory (HYSPLIT) model (Stein et al. 2015) at 3 altitudes (1500, 3000 and $5000 \mathrm{~m})$.

\section{Results and discussion}

Spring of 2015 had average incoming global solar radiation relative to longterm figures for Hornsund. In April 2015 the total sum of the global solar radiation was 301.2 $\mathrm{MJm}^{-2}$, while in May it was 510.0 $\mathrm{MJm}^{-2}$. In the years 1979-2009 averages for the same months were $297.4 \mathrm{MJm}^{-2}$ and 505.0 $\mathrm{MJm}^{-2}$, respectively (Styszyńska 2013), which is to say, close to 2015 averages (Fig. 2). Data from Isfjord Radio to the north of Hornsund for the earlier period of 1951-1960 show that the 2015 season under analysis in Hornsund did not vary significantly from the average for that area. The average total global solar radiation at Isfjord Radio was $311 \mathrm{MJm}^{-2}$ in April, and $488 \mathrm{MJ} \mathrm{m}^{-2}$ in May (Spinnangr 1968 after Głowicki 1985). The clearness index at both locations was 0.46 , and closely correlated to cloudiness (the correlation coefficient was -0.9), which was 5.9 oktas in April and 6.2 oktas in May. Hornsund demonstrates a high degree of cloudiness with a maximum observed from June to September (Lipiński and Łupikasza 2016). The course of cloudiness from June and August maxima based on data from 2007 has been described by Kotarba and Widawski (2008). Cloudiness for the period of analysis was slightly higher than the Hornsund average. The average cloudiness for 1978-2009 was 5.4 oktas for April, and 6.0 oktas for May (Marsz 2013). Despite slightly higher cloudiness, the average monthly sunshine duration for May (8.2 hours) was higher than in April (5.7 hours) due to the length of day, which was significantly greater, on average, in May (24 hours) than in April (19.8 hours). The combined sum of hours of sunshine in April was 171.8, so was slightly lower than the 1978-2009 average of 188.7 hours for Hornsund. In May of the year under analysis, sunshine duration was 254.3 hours, which 


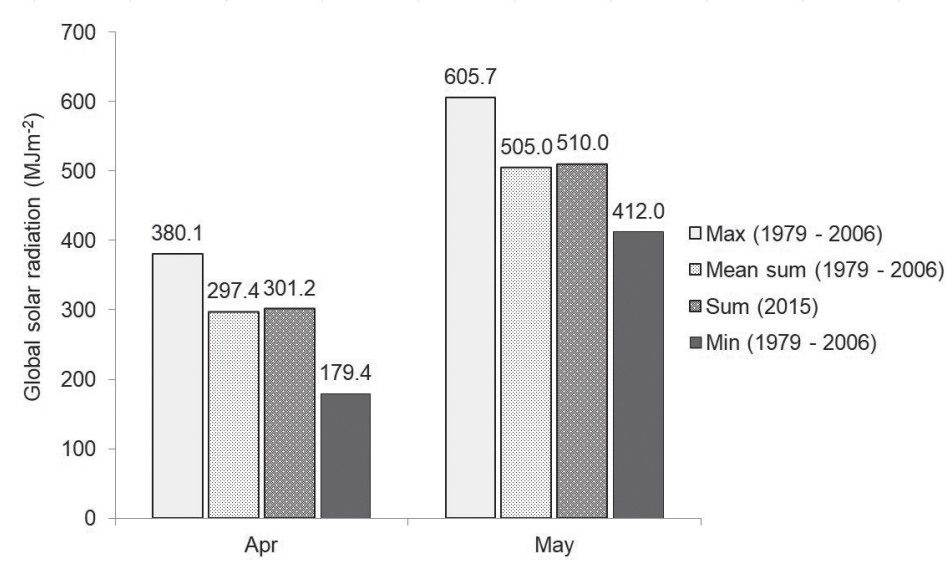

Fig. 2. Global solar radiation in Hornsund in 1979-2006 (average, highest, lowest) (Styszyńska 2013) and spring of 2015 (sum).

was significantly higher than the average sum of 208.1 for that month over the multi-year period (Marsz 2013). At the same time, spring in Hornsund has the highest sunshine duration values of any period in the annual cycle (Matuszko et al. 2015). This is associated with low cloudiness, which is in turn associated with the systems of highs which predominate in this time (Przybylak 1992; Niedźwiedź 2013). Day length in the period under analysis grew from 14.6 hours for April 1 to 24 hours from April 25 onwards. The solar elevation angle at solar noon also increased progressively from $17.6^{\circ}$ to $34.9^{\circ}$ between April 1 and May 31 .

The course of daily totals of global radiation for the analysed period is connected with day length, and with sunshine duration and cloudiness (Fig. 3). The lowest totals occur in the period before the onset of the polar day. The clearness index on the other hand depends mainly on cloudiness and also shows a high correlation with sunshine duration (Fig. 3). Its values were seen to decrease around mid-April and the mid-May. At that time there was also an increase in cloudiness and a reduction in sunshine duration (Fig. 3).

Incoming solar radiation also depends on atmospheric transparency, which is determined by its aerosol and water vapour content. Aerosol effect is mostly given by AOD, and particle size by the Ångström exponent. Atmospheric water vapour content is given as a layer (in $\mathrm{cm}$ ) of precipitable water in a vertical column of atmosphere.

Average AOD at $500 \mathrm{~nm}$ was 0.087 , which is typical for this season in Hornsund (Table 1) (Pakszys et al. 2015). Over the course of the year, the threshold of winter to spring has the highest AOD values. This is due to the influx at this time of pollutants from anthropogenic sources and forest fires from the middle latitudes (Rozwadowska et al. 2008). This phenomenon is known as "an arctic haze" and causes an increase of more than 0.1 in AOD 


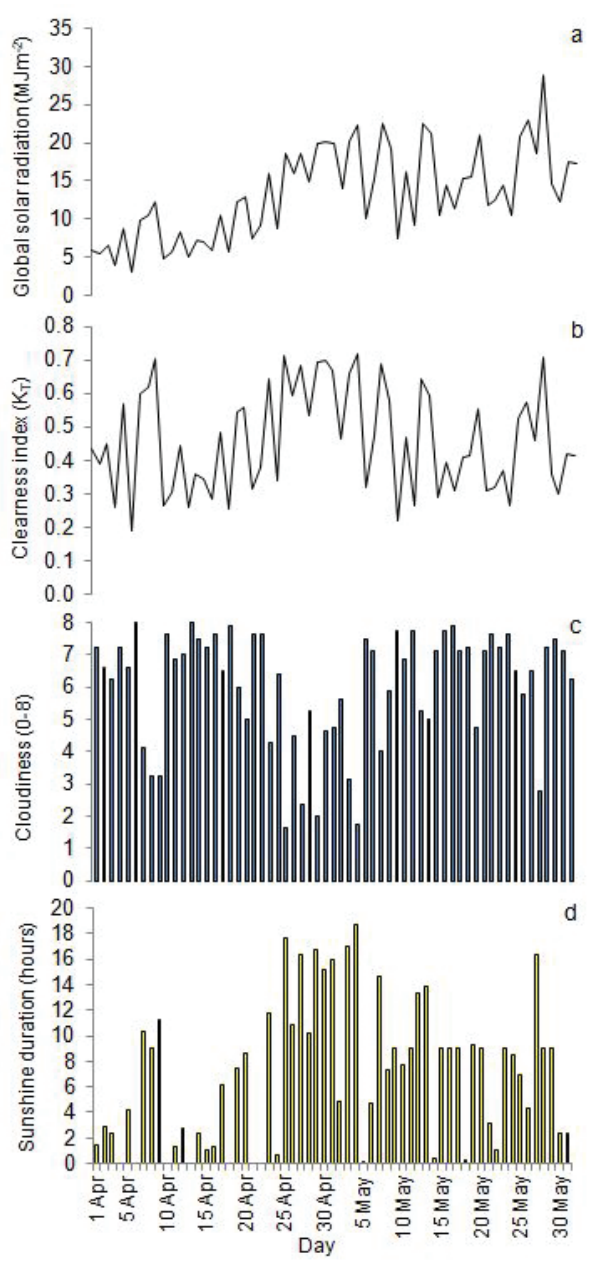

Fig. 3. Changes in (a) global solar radiation (daily total), (b) clearness index, (c) daily amounts of cloudiness and (d) daily totals of sunshine duration in Hornsund, spring of 2015.

(Rozwadowska et al. 2008). Over the analysed period in Hornsund the lowest observed value of AOD at $500 \mathrm{~nm}$ was 0.047 , while the highest was 0.143 . Seven instances were observed of AOD values exceeding the analysed data set's combined average total and standard deviation. These instances occurred on 3 days: $8^{\text {th }}$ of April, $26^{\text {th }}$ April and $4^{\text {th }}$ of May. The latter two days saw particularly high values. The greatest frequency of AOD readings at $500 \mathrm{~nm}$ in the analysed data set occurred in the 0.09 to 0.1 range, which comprised as much as $34.0 \%$ of all readings. Second place is held by even lower AOD readings ( 0.07 to 0.08$)$ which comprised $34.5 \%$ of the data set. The total of all instances of AOD above 0.1 is $22.6 \%$ (Fig. 4). 


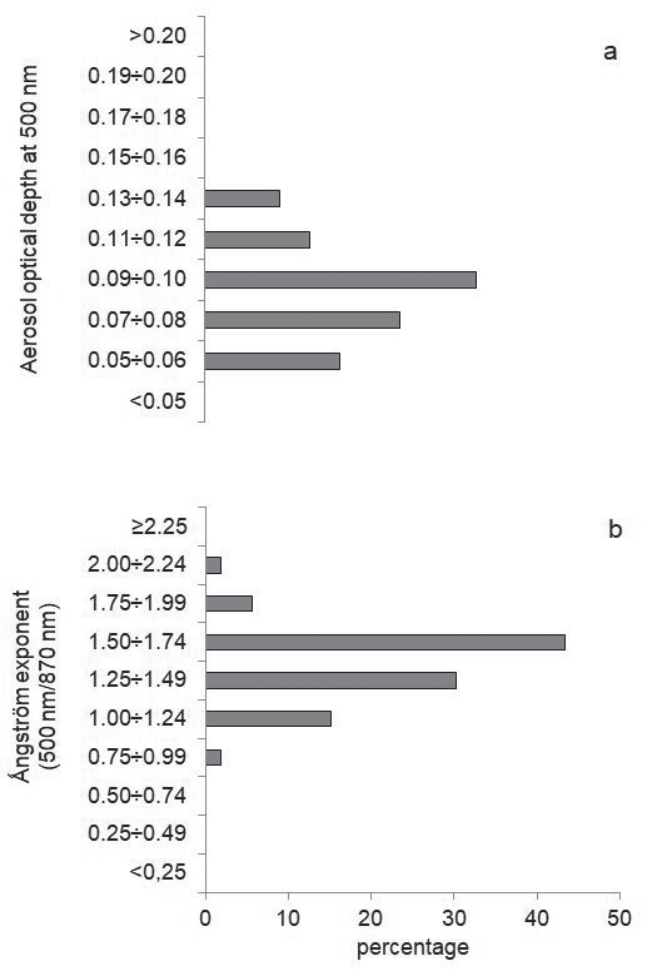

Fig. 4. Frequency of (a) AOD values at $500 \mathrm{~nm}$ and (b) the Ångström exponent (AE, 500/870) in Hornsund, spring of 2015.

The Ångström exponent averaged 1.48 for the analysed period in Hornsund (Table 1). Its individual values occurred in the 0.88 to 2.05 range. The highest frequency of $\mathrm{AE}$ values fell in the 1.50 to 1.74 range, and represented $43 \%$ of all instances (Fig. 4). This range and the neighbouring 1.25 to 1.49 range jointly constituted almost $74 \%$ of all instances (Fig. 4). Precipitable water content in the atmosphere was low, ranging from $0.22 \mathrm{~cm}$ to $0.56 \mathrm{~cm}$ (Table 1). AOD values at $500 \mathrm{~nm}$ relative to the Ångström exponent are presented in Fig. 5.

Additional information about aerosols is supplied by the NAAPS (Navy Aerosol Analysis and Prediction System) model of pollutant transport. Figure 6 presents average daily values of AOD of four types of aerosol at wavelength $550 \mathrm{~nm}$, obtained on the basis of data from the NAAPS model re-analysis. The data presented show that, in the period under discussion, one major aerosol event occurred (13-15 th of April), when AOD rose above 0.2. Over these days approximately half of the composition of the AOD was comprised of marine aerosols and just under 30\% was of anthropogenic origin. Unfortunately, due to cloudiness, no photometric measurements were taken. In the remaining days only a few instances of optical depth over 0.1 were observed. Over April-May 
Table 1

Average, maximum and minimum values of aerosol optical depth (AOD), Ångström exponent (AE) and atmospheric precipitable water content in Hornsund, spring of 2015.

\begin{tabular}{|c|c|c|c|c|c|c|c|}
\hline Date & Parameter & AOD380 & AOD500 & AOD870 & AOD1020 & AE500/870 & $\begin{array}{l}\text { Precipitable } \\
\text { water }(\mathrm{cm})\end{array}$ \\
\hline \multirow{3}{*}{08 Apr 2015} & mean & 0.157 & 0.105 & 0.036 & 0.036 & 1.93 & 0.50 \\
\hline & $\max$ & 0.162 & 0.111 & 0.039 & 0.039 & 2.05 & 0.50 \\
\hline & $\min$ & 0.148 & 0.098 & 0.032 & 0.032 & 1.85 & 0.49 \\
\hline \multirow{3}{*}{09 Apr 2015} & mean & 0.111 & 0.080 & 0.039 & 0.048 & 1.32 & 0.50 \\
\hline & $\max$ & 0.115 & 0.088 & 0.049 & 0.061 & 1.49 & 0.51 \\
\hline & $\min$ & 0.107 & 0.074 & 0.034 & 0.038 & 1.07 & 0.49 \\
\hline \multirow{3}{*}{25 Apr 2015} & mean & 0.095 & 0.069 & 0.034 & 0.047 & 1.33 & 0.25 \\
\hline & $\max$ & 0.112 & 0.087 & 0.049 & 0.063 & 1.58 & 0.28 \\
\hline & $\min$ & 0.078 & 0.056 & 0.024 & 0.035 & 0.88 & 0.22 \\
\hline \multirow{3}{*}{26 Apr 2015} & mean & 0.158 & 0.118 & 0.063 & 0.076 & 1.17 & 0.40 \\
\hline & $\max$ & 0.186 & 0.143 & 0.082 & 0.096 & 1.34 & 0.43 \\
\hline & $\min$ & 0.136 & 0.099 & 0.047 & 0.061 & 1.01 & 0.39 \\
\hline \multirow{3}{*}{27 Apr 2015} & mean & 0.118 & 0.084 & 0.034 & 0.048 & 1.64 & 0.35 \\
\hline & $\max$ & 0.136 & 0.095 & 0.037 & 0.052 & 1.72 & 0.37 \\
\hline & $\min$ & 0.107 & 0.074 & 0.029 & 0.044 & 1.60 & 0.33 \\
\hline \multirow{3}{*}{29 Apr 2015} & mean & 0.119 & 0.089 & 0.038 & 0.053 & 1.56 & 0.33 \\
\hline & $\max$ & 0.140 & 0.106 & 0.044 & 0.063 & 1.63 & 0.34 \\
\hline & $\min$ & 0.096 & 0.065 & 0.028 & 0.043 & 1.48 & 0.32 \\
\hline \multirow{3}{*}{04 May 2015} & mean & 0.147 & 0.103 & 0.042 & 0.055 & 1.64 & 0.34 \\
\hline & $\max$ & 0.183 & 0.130 & 0.058 & 0.066 & 1.75 & 0.37 \\
\hline & $\min$ & 0.124 & 0.087 & 0.034 & 0.044 & 1.46 & 0.32 \\
\hline \multirow{3}{*}{12 May 2015} & mean & 0.105 & 0.077 & 0.037 & 0.055 & 1.34 & 0.54 \\
\hline & $\max$ & 0.115 & 0.085 & 0.045 & 0.065 & 1.49 & 0.54 \\
\hline & $\min$ & 0.097 & 0.070 & 0.033 & 0.049 & 1.16 & 0.53 \\
\hline \multirow{3}{*}{27 May 2015} & mean & 0.074 & 0.050 & 0.023 & 0.043 & 1.43 & 0.55 \\
\hline & $\max$ & 0.081 & 0.055 & 0.024 & 0.049 & 1.48 & 0.56 \\
\hline & $\min$ & 0.071 & 0.047 & 0.022 & 0.038 & 1.35 & 0.53 \\
\hline \multirow{3}{*}{ Apr-May2015 } & mean & 0.121 & 0.087 & 0.039 & 0.053 & 1.48 & 0.39 \\
\hline & $\max$ & 0.186 & 0.143 & 0.082 & 0.096 & 2.05 & 0.56 \\
\hline & $\min$ & 0.071 & 0.047 & 0.022 & 0.032 & 0.88 & 0.22 \\
\hline
\end{tabular}




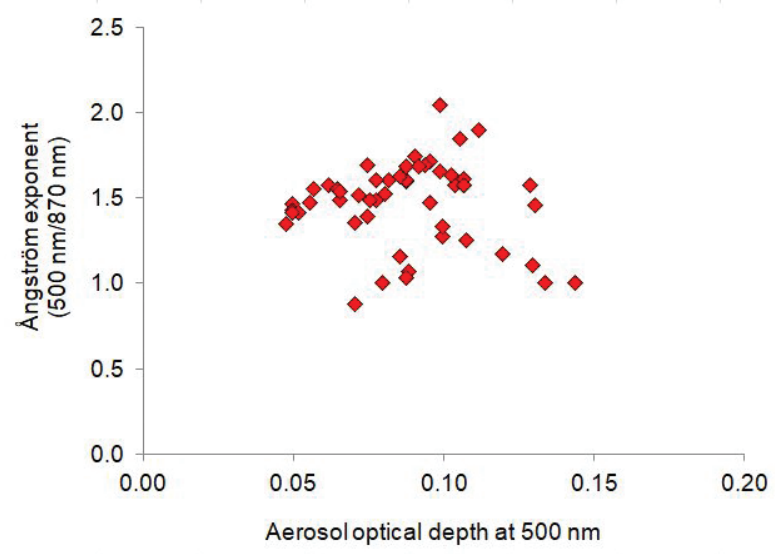

Fig. 5. Ångström exponent (AE, 500/870 nm) as a function of the aerosol optical depth (AOD) at $500 \mathrm{~nm}$ and in Hornsund in spring of 2015.

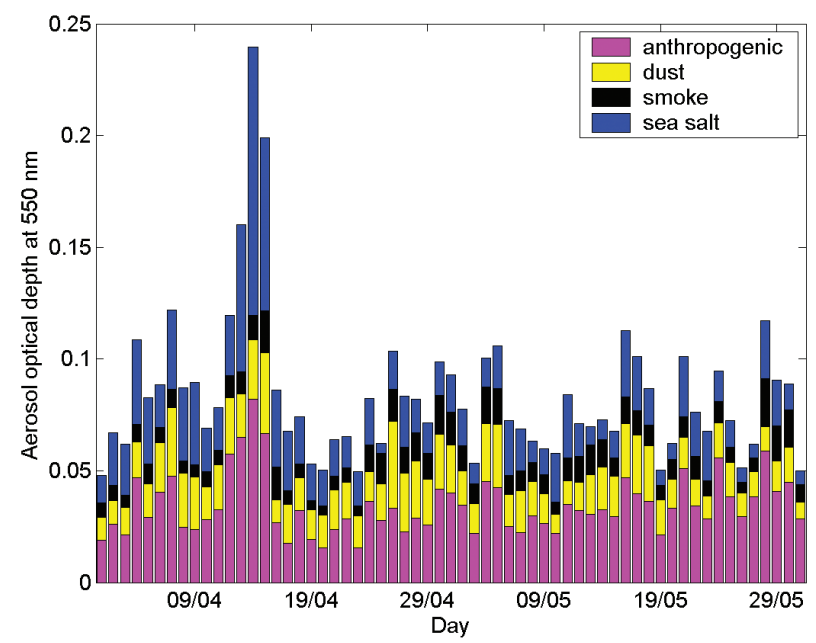

Fig. 6. Temporal variability of daily mean AOD at $550 \mathrm{~nm}$ for anthropogenic, mineral dust, smoke and sea-salt particles obtained from NAAPS reanalysis.

(Fig. 7) the greatest part of optical depth was comprised of anthropogenic aerosols $(41 \%)$, followed by marine aerosols $(26 \%)$, desert dust $(21 \%)$ and biomassburning aerosols (12\%).

Incoming solar radiation also depends on atmospheric circulation. Baric systems cause the inflow of air from varying source regions. Inflowing air masses differ from one another in moisture content and aerosols of both anthropogenic 


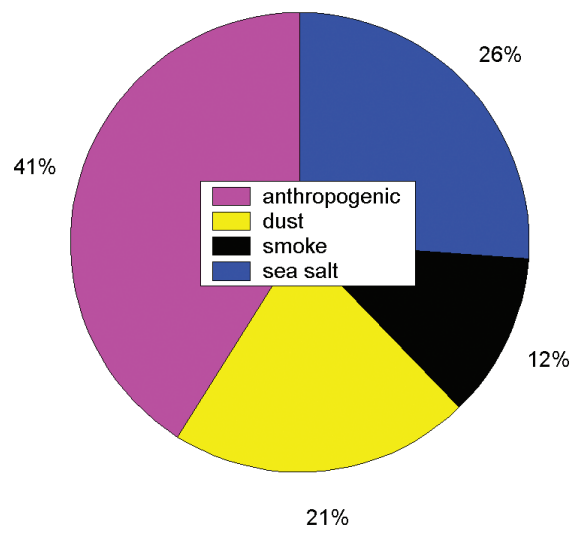

Fig. 7. Participation of anthropogenic, mineral dust, smoke and sea-salt particles in total aerosol optical depth at $550 \mathrm{~nm}$, from NAAPS model.

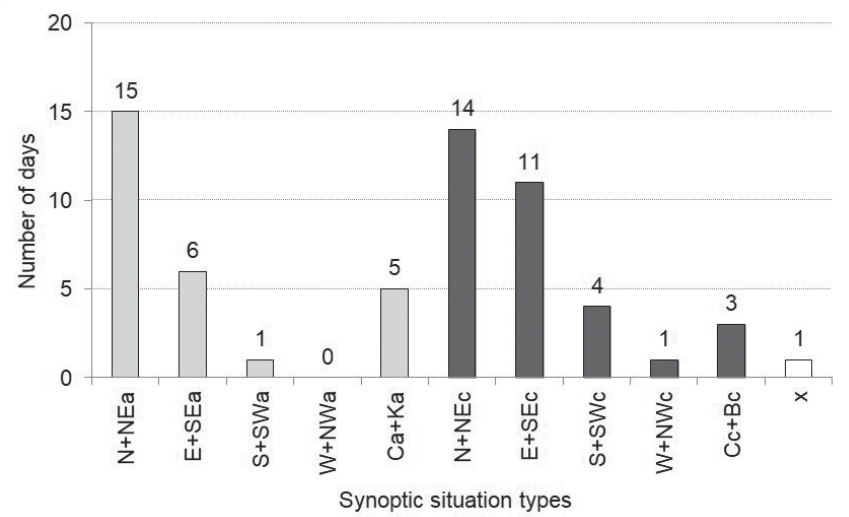

Fig. 8. Synoptic situation over Hornsund, spring of 2015.

and natural origin. Over the analysed months, cyclonic types occurred on $54.1 \%$ of days, and anticyclonic on $44.3 \%$ (Fig. 8). The greatest frequency of situations was those with air inflow from $\mathrm{N}$ and $\mathrm{NE}$, both anticyclonic (15 days) and cyclonic (14 days). Inflow of air mass from $\mathrm{E}$ and SE were also significant in situations both cyclonic (11 days) and anticyclonic (6 days). The study only took into account situations which occurred on at least 5 days. This means that, apart from those mentioned above, the central anticyclonic situation and anticyclonic ridge ( $\mathrm{Ca}$ and $\mathrm{Ka}$ ) were also taken into account.

The greatest incoming radiation occurred during inflow of air masses from the $\mathrm{N}$ and NE during anticyclonic situations and, to a slightly lesser extent, during cyclonic situations (Fig. 9). The lowest radiation totals were observed for central anticyclonic situations and anticyclonic wedges, and in cyclonic 

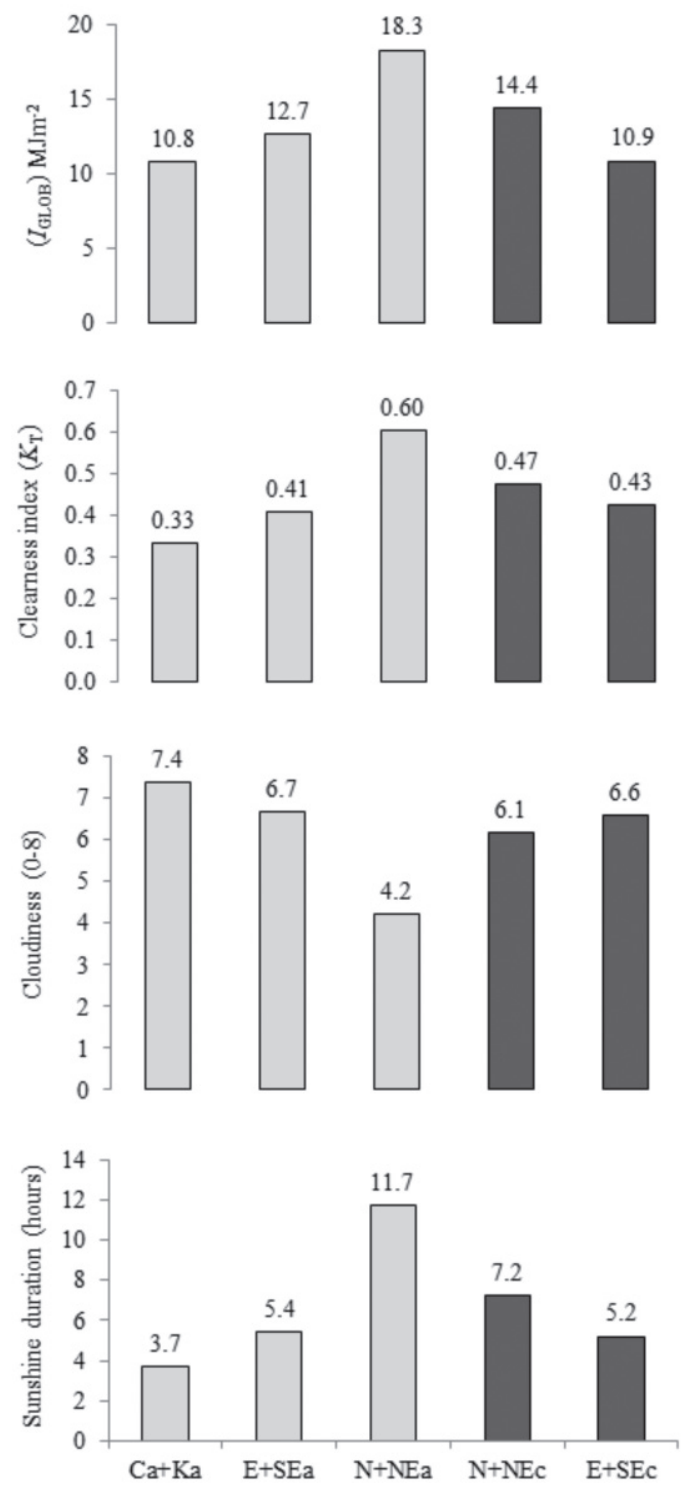

Fig. 9. Average daily incoming solar radiation $\left(I_{\mathrm{GLOB}}\right)$, clearness index $\left(K_{\mathrm{T}}\right)$, cloudiness and sunshine duration for selected synoptic situations in Hornsund in spring of 2015.

situations with air mass inflowing from the $\mathrm{S}$ and SE. Similar relationships exist for the clearness index (Fig. 9).

The direction of air mass inflow and type of baric system occurring over Hornsund also had an effect on the extent of cloudiness (Fig. 9). Decidedly below-average cloudiness was observed in anticyclonic situations with air mass 
inflow from the $\mathrm{N}$ and NE. Daily average cloudiness for this synoptic situation was 4.2 oktas. Meanwhile, the greatest levels of cloudiness occurred when Hornsund found itself within a central anticyclonic situation or anticyclonic ridge, and reached as much as 7.4 oktas. In all other analysed synoptic situations, cloudiness was fairly uniform, at over 6 oktas.

Because cloudiness shows a strong correlation with sunshine duration, in the analysed period in Hornsund the greatest number of sunshine hours occurred in anticyclonic situations with air mass inflow from the $\mathrm{N}$ and $\mathrm{NE}$, while the least occurred in situations $\mathrm{Ca}$ and $\mathrm{Ka}$ (Fig. 9). Of the remaining synoptic situations the greatest number of sunshine hours is seen for cyclonic conditions with air mass inflow from $\mathrm{N}$ and $\mathrm{NE}$.

Table 2

Frequency of air mass inflow from specific directions (144-hour back trajectories) and extent of solar radiation, clearness index, cloudiness and sunshine duration in Hornsund in the spring of 2015.

\begin{tabular}{|c|c|c|c|c|c|c|c|c|}
\hline \multirow{2}{*}{$\begin{array}{c}\text { Altitude } \\
\text { (m a.s.l.) }\end{array}$} & \multicolumn{8}{|c|}{ Direction of advection } \\
\hline & $\mathrm{N}$ & NE & $\mathrm{E}$ & SE & $\mathrm{S}$ & SW & W & NW \\
\hline \multicolumn{9}{|c|}{ Number of cases } \\
\hline 1500 & 1 & 4 & 7 & 13 & 6 & 19 & 7 & 4 \\
\hline 3000 & 1 & 2 & 4 & 6 & 6 & 28 & 9 & 5 \\
\hline 5000 & 1 & 2 & 5 & 9 & 8 & 29 & 5 & 2 \\
\hline \multicolumn{9}{|c|}{ Global solar radiation $\left(\mathrm{MJm}^{-2}\right)$} \\
\hline 1500 & 15.3 & 14.1 & 17.7 & 10.6 & 13.7 & 12.6 & 15.8 & 11.7 \\
\hline 3000 & 14.6 & 18.3 & 18.1 & 11.9 & 9.6 & 12.6 & 14.7 & 14.8 \\
\hline 5000 & 3.9 & 17.1 & 16.4 & 14.1 & 11.7 & 12.6 & 15.3 & 15.0 \\
\hline \multicolumn{9}{|c|}{ Clearness index $\left(K_{\mathrm{T}}\right)$} \\
\hline 1500 & 0.47 & 0.47 & 0.57 & 0.37 & 0.44 & 0.45 & 0.55 & 0.49 \\
\hline 3000 & 0.36 & 0.58 & 0.58 & 0.43 & 0.33 & 0.43 & 0.54 & 0.55 \\
\hline 5000 & 0.26 & 0.56 & 0.60 & 0.46 & 0.43 & 0.43 & 0.52 & 0.49 \\
\hline \multicolumn{9}{|c|}{ Cloudiness $(0-8)$} \\
\hline 1500 & 7.1 & 6.0 & 4.1 & 6.9 & 6.7 & 6.1 & 5.6 & 5.9 \\
\hline 3000 & 7.3 & 4.8 & 4.4 & 6.2 & 7.3 & 6.4 & 5.4 & 5.4 \\
\hline 5000 & 7.3 & 4.4 & 4.3 & 6.1 & 6.4 & 6.5 & 5.3 & 6.1 \\
\hline \multicolumn{9}{|c|}{ Sunshine duration (hours) } \\
\hline 1500 & 4.7 & 4.9 & 11.7 & 6.2 & 6.4 & 6.1 & 8.9 & 5.6 \\
\hline 3000 & 9.0 & 9.8 & 11.6 & 7.3 & 6.4 & 5.4 & 9.2 & 7.0 \\
\hline 5000 & 0.0 & 11.0 & 11.1 & 7.8 & 7.3 & 5.6 & 8.4 & 8.1 \\
\hline
\end{tabular}


The problem of the influence of circulation on the amount of radiation reaching the earth's surface in Hornsund in spring of 2015 was also studied in relation to the back trajectories of air masses. Using the HYSPLIT model, 144-hour back trajectories were simulated at altitudes of $1500 \mathrm{~m}, 3000 \mathrm{~m}$ an $5000 \mathrm{~m}$. The analyses indicated that air masses most commonly flowed in from the SW and $\mathrm{SE}$, and most rarely from the $\mathrm{N}$ and NE (Table 2). As the frequency of occurrence of individual directions indicating the source region of air masses was variable, the results obtained for hardly represented directions should be interpreted with caution. The greatest insolation occurred when the source region of air masses lay to the $\mathrm{N}$ and $\mathrm{NE}$ of Hornsund, i.e. with air mass inflow from the northern polar regions. Decidedly lower insolation was seen when the source region of air masses lay in the SE-S-SW sector, i.e. with air masses coming from over Europe and Asia (Table 2). With inflow of air from NE and $\mathrm{E}$, the clearness index was high (up to 0.60), cloudiness was low and sunshine duration high. Therefore, conditions were conducive to high incoming solar radiation to the earth's surface (Table 2). The situation is the opposite when air masses are inflowing from the SE-S-SW sector, when incoming solar radiation is significantly lower (Table 2).

\section{Concluding remarks}

Incoming global solar radiation to the earth's surface depends on many factors, meaning that it is time variable. The spring season under analysis at the Hornsund station turned out to be average with regard to the long-term incoming radiation (Styszyńska 2013). The clearness index was the same for both studied months, at 0.46 . This means that solar radiation reaching the earth's surface, as a percentage of the solar constant, was the same in both months. This occurred largely due to cloudiness, which in May was close to that of April. The station in Hornsund is typified by high levels of cloudiness (Marsz 2013), which is a factor heavily limiting the incoming solar radiation. Over the annual cycle it is spring that experiences the maximum sunshine duration (Marsz and Styszyńska 2013). Sunshine duration in May was greater than in April, which is associated with an increase in day length (the solar day lasts through the whole of May).

Incoming solar radiation to the earth's surface is also affected by the optical conditions of the atmosphere. AOD changes with time and location. Particularly large changes in the annual cycle are visible in the Arctic (Rozwadowska and Sobolewski 2010). In the annual cycle the greatest AOD values occur in late winter and in spring, while considerably lower values occur in summer (Quinn et al. 2007; Tomasi et al. 2007; Rozwadowska and Sobolewski 2010; Toledano 2012). AOD values can also be elevated as a result of volcanic eruptions (Karasiński et al. 2014), forest fires, dust flows, etc. The average AOD at $500 \mathrm{~nm}$ in spring of 2015 in Hornsund was 0.087. For comparison, the average there for 2005-2008 was 0.110 (Rozwadowska 
and Sobolewski 2010). In the analysed period, increased values of AOD at $500 \mathrm{~nm}$ (up to 0.143) were observed, although these are not record values. In the years 2005-2008 the peak value of AOD at $500 \mathrm{~nm}$ occurred on May 22006 and was 0.412 (Rozwadowska and Sobolewski 2010). Results from the pollutant transport model indicate that the main type of aerosol in this period was anthropogenic aerosol $(41 \%)$. The fairly high participation of marine aerosols $(26 \%)$ indicates a significant influence of wind associated with mesoscale weather systems.

The greatest inflow of global solar radiation occurred when Hornsund was within an anticyclone and air masses were inflowing from the $\mathrm{N}$ and $\mathrm{NE}$. The lowest radiation reached the Earth's surface in central anticyclonic situations and anticyclonic wedges. This was most probably "anticyclonic gloom", i.e. highs characterised by cloudy weather. The 144-hour back trajectories also indicate that the highest incoming radiation occurs with air mass inflow from the NE and $\mathrm{N}$, and least with inflow from the SE-S-SW sector.

Acknowledgements. - The research work was supported by the Polish Norwegian Fund as part of the 'Arctic Climate System Study of Ocean, Sea Ice and Glaciers Interactions in the Svalbard Area' project (AWAKE 2) and by a grant entitled 'Contemporary and historical changes in the Svalbard climate and topoclimates', funded by the National Science Centre with decision No. DEC-2011/03/B/ST10/05007. The authors wish to thank the Institute of Geophysics of the Polish Academy of Sciences in Warsaw for making accessible data on cloudiness and sunshine duration, and Tadeusz Niedźwiedź for making available the catalogue of atmospheric circulation over Spitsbergen. Special thanks for help in improving the manuscript are for two reviewers Tadeusz Niedźwiedź and Andrzej Z. Kotarba.

\section{References}

Budyko M.I. 1971. Climate and life. Gidrometeoizdat, Leningrad: 470 pp. (in Russian).

GavriLova M.K. 1963. Radiation Climate of the Arctic. Gidrometeoizdat, Leningrad: 225 pp. (in Russian).

GŁOWICKI B. 1985. Radiation conditions in the Hornsund area (Spitsbergen). Polish Polar Research 6: $301-318$

HARTMANN D.L. 1994. Global physical climatology. Academic Press, San Diego: 411 pp.

Karasiński G., PosyniaK M., Bloch M., Sobolewski P., MaŁARZEWSKi Ł. and SoroKa J. 2014. Lidar observations of volcanic dust over Polish Polar Station at Hornsund after eruptions of Eyjafjallajökull and Grimsvötn. Acta Geophysica 62: 316-339.

KOTARBA A., WIDAWSKI A. 2008. The satellite cloud climatology in 2007 above Svalbard in relation to atmospheric circulation conditions. Problemy Klimatologii Polarnej 18: 127-140 (in Polish).

Lisok J., Markowicz K.M., Ritter C., Neuber R., Makuch P., PAKSzys P., Markuszewski P., Petelski T., RozWAdowsKa A., Zielinski T., Chilinski M., STACHLEWSKa I.S., BeCAGLi S., TraVersi R., Udisti R., StRUZEWSKA J., KAMINSKI J.W. and JEFIMOW M. 2016. 2014 iAREA campaign on aerosol in Spitsbergen - Part 1: Study of physical and chemical properties. Atmospheric Environment 140: 150-165. 
LIPIŃSKI O. and ŁUPIKASZA E. 2016. The role of atmospheric circulation in shaping total cloudiness over Spitsbergen (1983-2013). Przeglad Geograficzny 88: 317-337 (in Polish).

MARsz A.A. 2013. Cloudiness and sunshine duration. In: A.A. Marsz and A. Styszyńska (eds) Climate and climate change at Hornsund, Svalbard. The publishing house of Gdynia Maritime University, Gdynia: 101-125.

MARShunOVA M.S. and CHERNIGOVSKII N.T. 1971. Radiation Regime of the Foreign Arctic. Gidrometeoizdat, Leningrad: $182 \mathrm{pp}$. (in Russian).

Matuszko D., Celiński-MysłaW D. and Soroka J. 2015. Sunshine duration in the European arctic and Greenland based on the data from selected stations in the polar regions. Problemy Klimatologii Polarnej 25: 127-138 (in Polish).

NiEDŹWIEDŹ T. 2013. The atmospheric circulation. In: A.A. Marsz and A. Styszyńska (eds) Climate and climate change at Hornsund, Svalbard. The publishing house of Gdynia Maritime University, Gdynia: $57-74$.

NiEDŹWIEDŹ T. 2016. A catalogue of circulation types for Spitsbergen, digital collection. Department of Climatology, University of Silesia, Sosnowiec.

OHMURA A. 1981. Climate and energy balance of Arctic tundra. Zürcher Geographische Schriften, 3, Zürich: 448 pp.

OHMURA A. 1982. A historical review of studies on the energy balance of Arctic tundra. International Journal of Climatology 2: 185-195.

Pakszys P., Zieliński T., Markowicz K., Petelski T., MaKuch P., LisoK J., Chiliński M., RoZWADOWSKA A., RITTER CH., NEUBER R., Udisti R. and MAZZOLA M. 2015. Annual changes of aerosol optical depth and Ångström exponent over Spitsbergen. In: T. Zieliński, M. Węsławski and K. Kuliński, (eds), Impact of climate changes on marine environments, GeoPlanet: Earth and Planetary Sciences, Springer, Switzerland: 148 pp.

PRZYBYLAK R. 1992. Air temperature and humidity relations at Hornsund /Spitsbergen/ in the period 1978-1983 on the background of atmospheric circulation. Dokumentacja Geograficzna 2: 1-105 (in Polish).

PRZYBYLAK R. 2016. The climate of the Arctic. Springer: 287 pp.

Quinn P.K., Shaw G., Andrews E., DutTon E.G., RuOHO - Airola T. and Gong L. 2007. Arctic haze: current trends and knowledge gaps. Tellus 59B: 99-114.

RozWAdOWSKa A., Petelski T. and Zieliński T. 2008. Aerosol measurements in Hornsund during XXIX PAS Polar Expedition. Problemy Klimatologii Polarnej 18: 161-170 (in Polish).

ROZWADOWSKA A., SOBOLEWSKI P. 2010. Variability in aerosol optical properties at Hornsund, Spitsbergen. Oceanologia 52: 599-620.

Rozwadowska A., Zieliński T., Petelski T. and Sobolewski P. 2010. Cluster analysis of the impact of air back-trajectories on aerosol optical properties at Hornsund, Spitsbergen. Atmospheric Chemistry and Physics 10: 877-893.

SPINNANGR G. 1968. Global radiation and duration of sunshine in Northern Norway and Spitsbergen. Meteor. Annaler 5, 3: 66-112.

STYSZYŃSKA A. 2013. Solar radiation. In: A.A. Marsz and A. Styszyńska (eds) Climate and climate change at Hornsund, Svalbard. The publishing house of Gdynia Maritime University, Gdynia: 117-143.

Stein A.F., DraXler R.R., RolPh G.D., Stunder B.J.B., COHEN M.D. and NGAN F. 2015. NOAA's HYSPLIT atmospheric transport and dispersion modelling system. Bulletin of the American Meteorological Society 96.2059-2077.

Toledano C., Cachorro V.E., Gausa M., Stebel K., Aaltonen V., Berjón A., Ortiz de Galisteo J.P., DE Frutos A.M., BennounA Y., Blindheim S., Myhre C.L., Zibordi G., Wehrli C., Kratzer S., Hakansson B., Carlund T., De Leeuw G., Herber A. and Torres B. 
2012. Overview of sun photometer measurements of aerosol properties in Scandinavia and Svalbard. Atmospheric Environment 52: 18-28.

Tomasi C., Vitale V., Lupi A., Di Carmine C., Campanelli M., Herber A., TrefFeisen R., Stone R.S., ANDrews E., Sharma S., Radionov V., von Hoyningen-Huene W., STEbel K., Hansen G.H., Myhre C.L., Wehrli C., Aaltonen V., LiHaVainen H., VirkKUla A., Hillamo R., Ström J., Toledano C., CAChorro V.E., Ortiz P., DE Frutos A.M., Blindheim S., Frioud M., Gausa M., Zielinski T., Petelski T. and Yamanouchi T., 2007. Aerosols in polar regions: A historical overview based on optical depth and in situ observations. Journal of Geophysical Research 112: D16205.

Received 14 September 2016

Accepted 18 July 2017 